\title{
Analisis Kelayakan Usaha Ternak Ayam Arab Petelur Di Desa Leppangang Kecamatan Patampanua Kabupaten Pinrang
}

\author{
Feasibility Analysis of Laying Arab Chickens in Leppangang Village, Patampanua District, \\ Pinrang Regency
}

Nurwani $^{1 *}$, Nurhapsa ${ }^{1}$, Arman $^{1}$

"Email: nurwanisyam98@gmail.com

${ }^{1}$ Fakultas Pertanian, Peternakan dan Perikanan Universitas Muhammadiyah Parepare

Diterima: 12 September 2021 / Disetujui: 24 Desember 2021

\begin{abstract}
ABSTRAK
Penelitian ini bertujuan 1) untuk mengetahui besar biaya dan pendapatan rata-rata peternak dalam usaha ternak ayam arab petelur di Desa Leppanggang Kecamatan Patampanua Kabupaten Pinrang. 2) untuk mengetahui tingkat kelayakan usaha ternak ayam arab petelur ditinjau dari aspek finansial. 3) untuk menentukan tingkat kelayakan usaha ternak ayam arab petelur ditinjau dari aspek nonfiansial : aspek pemasaran, manajemen, teknis, hukum, sosial dan lingkungan. Jenis data dalam penelitian ini ada 2 yaitu data kualitatif dan data kuntitatif dan teknik pengumpulan data yang digunakan yaitu metode observasi, kuesioner, dan wawancara serta sumber data yang digunakan yaitu sumber data primer dan sekunder. Analisis data yang digunakan dalam penelitian ini adalah Statsitik deksriptif dan skala likert. Hasil penelitian menunjukkan bawah pendapatan rata-rata peternak ayam arab petelur senilai Rp. 9.200.644/ bulan, Tingkat kelayakan usaha beternak ayam arab petelur ditinjau dari analisis penerimaan atas biaya ( $\mathrm{R} / \mathrm{C}$ Rasio) diperoleh sebesar 2,7 hal tersebut manandakan bahwa usaha tersebut termasuk kedalam kategori Layak karena hasil R/C Ratio >1, sehingga dapat dikatakan usaha tersebut Layak untuk di kembangka dan Layak secara Finansial, Sedangkan berdasarkan hasil analisis tingkat kelayakan usaha ternak ayam arab petelur ditinjau dari aspek pemasaran, manajemen, teknis, hukum, sosial dan lingkungan, maka hasil penelitian menunjukkan secara kualitatif, hasil yang diperoleh rata-rata menunjukkan pada kategori Setuju sehingga secara kualitatif masuk kedalam kategori Layak secara Nonfinansial.
\end{abstract}

Kata Kunci: Ayam Arab Petelur, Aspek Finansial, Aspek Nonfinansial

\section{ABSTRACT}

This study aims 1) To determine the cost and average income of farmers in the laying hens business in Leppanggang Village, Patampanua District, Pinrang Regency. 2) To determine the level of feasibility of laying hens in terms of financial aspects. 3) To determine the feasibility level of laying hens in terms of non-financial aspects: marketing, management, technical, legal, social and environmental aspects. There are 2 types of data in this study, namely qualitative data and quantitative data and the data collection techniques used are observation, questionnaire, and interview methods and the data sources used are primary and secondary data sources. Analysis of the data used in this study is descriptive statistics and Likert scale. The results showed that the average income of laying arab chicken breeders was Rp. 9,200,644/month, the feasibility level of raising laying hens in terms of revenue analysis on costs $(R / C$ Ratio) is 2.7 , which indicates that the business is included in the Eligible category because the results of the $R / C$ Ratio are $>1$, so it can be said that the business is feasible to be developed and financially feasible, while based on the results of the analysis of the feasibility level of laying arab chickens in terms of marketing, management, technical, legal, social and environmental aspects, the results of the study show qualitatively, the results obtained are average. The average indicates the Agree category so that qualitatively it is included in the Non-financially Eligible category.

Keywords: Laying Arab Chicken, Financial Aspects, Non-Financial Aspects

(a) () This work is licensed under Creative Commons Attribution License 4.0 CC-BY International license 


\section{A. PENDAHULUAN}

Usaha sektor peternakan adalah salah satu bidang usaha yang memiliki peluang yang sangat besar untuk dikembangkan sebagai bidang usaha di masa depan, dan kebutuhan masyarakat akan produk-produk peternakan akan semakin meningkat setiap tahunnya.

Prospek usaha peternakan ayam petelur di nilai sangat baik, hal ini terlihat dari banyaknya perusahaan pembibitan, pakan ternak, dan obat-obatan yang masih berproduksi, dan usaha peternakan ayam petelur merupakan salah satu usaha yang sangat cepat mengalami perkembangan, karena pengaruhnya sebagai penghasil sumber protein yang murah dibandingkan dengan sumber protein hewani lainnya, sehingga siklus perputaran usaha sangat besar dan cepat.

Bila industri peternakan ayam petelur terus dikembangkan, ayam dan telur akan menjadi komoditi yang besar dan banyak mendatangkan keuntungan, salah satunya yaitu beternak ayam arab petelur yang dimana telur dari ayam arab mempunyai kemiripan dengan telur ayam kampung, baik dari segi kulit telur, maupun kandungan vitamin zat gizi) di dalamnya, sehingga seiring berjalannya waktu telur dari ayam arab merupakan salah satu alternatif pengganti telur ayam kampung yang makin langkah di pasaran.

$$
\text { Ayam arab (Gallus turcicus) }
$$

merupakan ayam kelas mediteral (bentuk badan lebih kecil dibandingkan dengan ayam kampung) dan merupakan hasil persilangan ayam arab dengan ayam buras, dan ayam arab mulai dikenal oleh masyarakat kira-kira tujuh tahun yang lalu. Menurut beberapa ilmuan ayam arab sudah mulai dikembangkan di Jawa Timur sejak 1990, ayam ini mulai digemari masyarakat karena mampu bertelur lebih banyak dari pada ayam ras (Pambudhi, 2003).

Prospek usaha peternakan ayam arab petelur di Kabupaten Pinrang sangat menjanjikan, karena sebagian telur dipasarkan di Pinrang maupun di luar daerah, namun masih sangat sedikit pelaku usaha di Kabupaten Pinrang khususnya masyarakat di Desa Leppangang Kecamatan Patampanua hanya terdapat \pm 10 masyarakat yang melakukan peternakan telur ayam arab petelur, hal ini di sebabkan karena masih kurangnya pemahaman masyarakat mengenai besar biaya dan tingkat pendapatan rata-rata yang akan diperoleh dalam melakukan usaha ternak ayam arab petelur dan sebahagian masyarakat mempunyai kebiasaan mengganti hewan 
ternaknya dengan hewan ternak yang populer pada saat itu hal tersebut di sebab kan karena masih kurangnya pemahaman peternak mengenai manfaat dan keunggulan apa saja yang dimiliki oleh ayam arab petelur di bandingkan ayam kampung.

Ayam arab termasuk dalam ayam petelur yang unggul karena memiliki kemampuan bertelur yang cukup tinggi dan juga ayam arab memiliki prospek bisnis yang menjanjikan karena permintaannya selalu bertambah, apalagi telur ayam arab adalah salah satu jenis komoditi bahan makanan yang mengandung nilai protein yang cukup tinggi, tentunya juga mengalami peningkatan permintaan pasar di berbagai wilayah, hal ini bisa diketahui ketika menjelang hari libur nasional seperti acara hari besar maka kebutuhan telur di pasaran juga akan ikut mengalami kenaikan.

Penelitian ini bertujuan 1) untuk mengetahui besar biaya dan pendapatan rata-rata peternak dalam usaha ternak ayam arab petelur di Desa Leppanggang Kecamatan Patampanua Kabupaten Pinrang. 2) untuk mengetahui tingkat kelayakan usaha ternak ayam arab petelur ditinjau dari aspek finansial. 3) untuk menentukan tingkat kelayakan usaha ternak ayam arab petelur ditinjau dari aspek nonfiansial : aspek pemasaran, manajemen, teknis, hukum, sosial dan lingkungan.

\section{B. METODE PENELITIAN}

\section{Waktu dan Tempat}

Penelitian ini dilaksanakan di Desa Leppangang Kecamatan Patampanua Kabupaten Pinrang. Desa Ini dipilih sebagai lokasi penelitian karena ada beberapa peternak ayam arab petelur yang berlokasikan di sekitar tempat tinggal saya dan melakukan usaha ternak ayam arab petelur di bawah kolom rumah, dan penelitian ini dilaksanakan selama 2 bulan mulai tanggal 28 September - 28 November 2020.

\section{Populasi dan Sampel}

Arikunto (2008), memberikan pengertian tentang Populasi adalah yaitu keseluruhan subyek penelitian. Dari pengertian tersebut dapat ditarik kesimpulan, bahwa populasi dalam penelitian ini meliputi segala sesuatu yang akan dijadikan subyek/obyek penelitian. Adapun yang menjadi Populasi dalam penelitian ini adalah peternak ayam arab sebanyak 10 peternak di Desa Leppangang Kecamatan Patampanua Kabupaten Pinrang.

Menurut Arikunto (2008), dalam penentuan pengambilan sampel apabila 
jumlah populasi kurang dari 100 lebih diambil semua. Jika jumlah populasinya lebih dari 100 maka dapat diambil minimal $10 \%$ dari jumlah populasi. Oleh karena itu jumlah populasi kurang dari 100, Maka Sampel dalam penelitian ini semua populasi yang berjumlah 10 populasi di Desa Leppangang Kecamatan Patampanua Kabupaten Pinrang yang dijadikan sampel.

\section{Teknik Pengumpulan Data}

Teknik yang digunakan pada penelitian ini yaitu teknik observasi, teknik wawancara dan teknik angket/ kuisioner.

\section{Analisis Data}

Analisis data yang digunakan dalam penelitian ini adalah pada aspek finansial menggunakan analisis data rasio penerimaan atas biaya (R/C Rasio), dan pada aspek non finansial menggunakan analisis Skala likert analisis deskriptift. Beberapa penjelasan mengenai alat analisis yang yang digunakan dalam penelitian ini dapat dilihat penjelasan berikit ini :

a. Analisis Biaya Usaha ternak / Biaya Produksi

Untuk mengetahui besarnya biaya dan pendapatan digunakan rumus Mulyadi (2009) :

$$
\mathrm{TC}=\mathrm{TFC}+\mathrm{TVC}
$$

Keterangan :

$\mathrm{TC}=$ Biaya Total $(\mathrm{Rp})$

$\mathrm{TFC}=$ Total Biaya Tetap $(\mathrm{Rp})$

$\mathrm{TVC}=$ Total Biaya Variabel $(\mathrm{Rp})$

b. Analisis Penerimaan Usaha Ternak Soekartawi, 2011, Penerimaan juga sangat ditentukan oleh besar kecilnya produksi yang dihasilkan dan harga dari produksi tersebut dan Penerimaan atau nilai produksi merupakan jumlah fisik produk dikalikan dengan harga yang sedang berlaku dengan Rumus penerimaan adalah sebagai berikut :

$$
\mathrm{TR}=\mathrm{Q} \times \mathrm{P}
$$

Keterangan :

$\mathrm{TR}=$ Nilai Produk atau Penerimaan Total $(\mathrm{Rp})$

$\mathrm{Q}=$ Total Produksi $(\mathrm{Rp})$

$\mathrm{P}=$ Harga jual Produk (Rp)

c. Analisis Pendapatan Usaha Ternak

Menurut Sukirno

(2006)

pendapatan adalah jumlah penghasilan yang diterima oleh penduduk atas prestasi kerjanya selama satu periode tertentu, baik harian, mingguan, bulanan maupun tahunan atau Pendapatan usaha ternak merupakan total penerimaan dikurangi dengan biaya produksi. Rumus pendapatan adalah sebagai berikut

$$
\boldsymbol{\pi}=\mathrm{TR}-\mathrm{TC}
$$

Keterangan :

$$
\begin{array}{ll}
\pi & =\text { Pendapatan (Rp) } \\
\text { TR } & =\text { Total Penerimaan (Rp) } \\
\text { TC } & =\text { Total Biaya (Rp) }
\end{array}
$$

d. Analisis Rasio Penerimaan atas Biaya Total/ Kelayakan.

Menurut Syamsuddin (2009), Untuk mengukur efisiensi usaha ternak dapat 
diketahui dari perbandingan antara total penerimaan dengan total biaya, yang dirumuskan sebagai berikut :

$$
\mathrm{R} / \mathrm{C} \text { ratio }=\frac{\mathrm{TR}}{\mathrm{TC}}
$$

Keterangan :

$\mathrm{R} / \mathrm{C}=$ Rasio Penerimaan Atas Biaya/ Retum cost rasio

TR $=$ Total Penerimaan $(\mathrm{Rp}) /$ Total revenue $\mathrm{TC}=$ Total Biaya $(\mathrm{Rp}) /$ Total cost

Latifah M (2007), menyatakan bahwa skala likert digunakan untuk mengukur sikap, pendapat, persepsi seseorang atau kelompok seseorang atau sekelompok tentang kejadian gejala sosial. Dengan menggunakan skala likert maka variable yang akan di ukur dijabarkan menjadi indikator-indikator yang dapat di ukur, dapat berupa menjadi pernyataan atau pertanyaan yang selanjutnya dikategorikan kedalam skor.

Instrumen yang digunakan dalam penelitian ini adalah lembar angket yang berisi beberapa pernyataan dengan lima sub variabel yakni indikator aspek pemasaran,teknis,hukum, manajemen, sosial dan lingkungan, dan desain pengukuran yang digunakan adalah skala likert dengan lima bagian skala, yaitu: sangat setuju, setuju, cukup setuju, tidak setuju, dan sangat tidak setuju. Untuk pengukuran setiap sub variabel penelitian dapat di kemukakan sebagai berikut :

$$
\mathrm{P} \frac{=\text { Rentang }}{\text { Banyak Kelas }}
$$

Keterangan:

$\mathrm{P} \quad=$ Panjang kelas interval

Rentang $=$ Data terbesar - data terkecil Banyak kelas $=5$

Hasil penjumlahan yang dilakukan maka dapat diperoleh rata-rata/skor untuk penetapan kriteria penilaian adalah sebagai berikut:

Dimana :

1. Nilai maksimum didasarkan atas skor jawaban tertinggi dikalikan dengan jumlah responden lalu dikalikan dengan jumlah kuesioner sebesar $5 \mathrm{x}$ jumlah responden $\mathrm{x}$ jumlah pernyataan dalam kuesioner

2. Nilai minimum didasarkan atas skor jawaban terendah dikalikan dengan jumlah responden lalu dikalikan dengan jumlah kuesioner sebesar 1 $\mathrm{x}$ jumlah responden $\mathrm{x}$ jumlah pernyataan dalam kuesioner

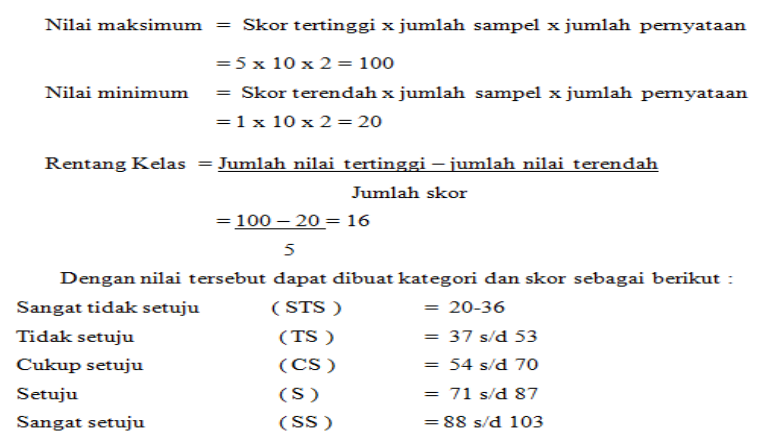

\section{HASIL DAN PEMBAHASAN}

\section{Aspek Finansial}

a. Biaya Variabel

Jumlah rata-rata biaya yang dikeluarkan secara keseluruhan oleh peternak dalam usaha ternak ayam arab 
petelur di Desa Leppangang Kecamatan Patampanua Kabupaten Pinrang dengan biaya variabel Rp.5.113.000/ Bulan-nya dan biaya tetap Rp. 164.757/ Bulan-nya, sehingga biaya rata-rata yang dikeluarkan oleh responden dalam usaha ini sebesar Rp. 5.277.357/ Bulannya.

Tabel 1. Rata-Rata Total Biaya Produksi Yang Digunakan Oleh Responden Usaha

Ternak Ayam Arab Petelur di Desa

Leppangang Kecamatan Patampanua Kabupaten Pinrang

\begin{tabular}{clc}
\hline No. & $\begin{array}{c}\text { Jenis biaya Yang } \\
\text { Digunakan }\end{array}$ & $\begin{array}{c}\text { Nilai Rata-Rata } \\
\text { (Rp/Bulan) }\end{array}$ \\
\hline 1 & Biaya tetap & 164.757 \\
2 & Biaya variable & 5.113 .000 \\
\hline & Jumlah Biaya & 5.277 .357 \\
\hline
\end{tabular}

\section{b. Biaya Variabel}

Untuk mengetahui komponen biaya variabel usaha ternak yang dikeluarkan oleh peternak dapat dilihat pada Tabel 2.

Tabel 2. Rata-rata Biaya Variabel Yang

Digunakan Oleh Responden Usaha

Ternak Ayam Arab Petelur di Desa Leppangang Kecamatan Patampanua Kabupaten Pinrang

\begin{tabular}{clc}
\hline No & $\begin{array}{c}\text { Jenis Biaya } \\
\text { Variabel }\end{array}$ & $\begin{array}{c}\text { Nilai Rata-Rata } \\
\text { (Rp/bulan) }\end{array}$ \\
\hline 1 & Pakan & 3.31 .500 \\
2 & Vaksin & 189.000 \\
3 & Obat-obatan & 77.500 \\
4 & Tenaga kerja & 620.000 \\
5 & Transprotasi & 800.000 \\
6 & Air dan listrik & 393.000 \\
\hline Jumlah biaya rata rata & 5.113 .000 \\
\hline
\end{tabular}

Tabel 2 menunjukkan rata- rata biaya variabel yang dikeluarkan oleh 10 peternak di Desa Leppangang Kecamatan Patampanua Kabupaten Pinrang yaitu sebesar Rp. 5.113.000. Dalam biaya variabel pakan mempunyai biaya yang cukup tinggi yang dikeluarkan oleh peternak karena pakan merupakan salah satu hal yang penting dalam usaha ternak, karena hewan ternak harus mengkomsumsi pakan yang memiliki nilai nutrisi yang seimbang untuk merangsang produktifitas telur agar menjadi lebih cepat bertelur.

\section{c. Biaya Tetap}

Untuk mengetahui komponen biaya tetap usaha ternak yang dikeluarkan oleh peternak dapat dilihat pada Tabel 3:

Tabel 3. Rata-rata Biaya Tetap Yang Digunakan Oleh Responden Usaha Ternak Ayam Arab Petelur di DesaLeppangang Kecamatan Patampanua Kabupaten Pinrang

\begin{tabular}{clc}
\hline No. & Jenis Biaya Tetap & $\begin{array}{c}\text { Nilai Rata-Rata } \\
(\mathbf{R p} / \text { Bulan })\end{array}$ \\
\hline 1 & Pajak & 36.000 \\
2 & penyusutanalat & 133.757 \\
\hline Jumlah Biaya tetap rata-rata & 164.357 \\
\hline \multicolumn{2}{c}{ Biaya tetap adalah biaya yang }
\end{tabular}
secara total tidak mengalami perubahan, walaupun ada perubahan banyaknya produksi atau penjualan dalam batas tertentu biaya pada dasarnya mempunyai arti jangka panjang dimana faktor-faktor produksi yang digunakan mempunyai faktor produksi tetap (Mulyadi, 2008). Pada usaha ternak ayam arab petelur yang termasuk biaya tetap adalah pajak dan penyusutan peralatan serta biaya lainnya. 


\section{d. Penerimaan Usaha Ternak}

Untuk mengetahui besar penerimaan rata-rata peternak dalam usaha ternak ayam arab petelur di Desa Leppangang Kecamatan Patampanua Kabupaten Pinrang dapat di lihat pada tabel di bawah ini.

Tabel 4. Rekapitulasi Penerimaan Usaha Ternak Ayam Arab Petelur di Desa Leppangang Kecamatan Patampanua Kabupaten Pinrang

\begin{tabular}{clr}
\hline No. & \multicolumn{2}{c}{ Uraian } \\
\hline 1 & Total rata-rata hasil produksi & $381 \mathrm{rak}$ \\
2 & Harga jual & 38.000 \\
\hline & Jumlah & 14.478 .000 \\
\hline
\end{tabular}

e. Pendapatan Usaha Ternak

Untuk mengetahui besar pendapatan rata-rata yang diterima oleh peternak dalam usaha ternak ayam arab petelur di Desa Leppangang Kecamatan Patampanua Kabupaten Pinrang dapat di lihat pada tabel di bawah ini.

Tabel 5. Rekapitulasi Pendapatan Usaha Ternak Ayam Arab Petelur di Desa Leppangang Kecamatan Patampanua

\begin{tabular}{clc}
\multicolumn{3}{c}{ Kabupaten Pinrang } \\
\hline No. & \multicolumn{2}{c}{ Uraian } \\
\hline 1 & Total penerimaan & 14.478 .000 \\
2 & Total biaya & 5.277 .357 \\
\hline & Jumlah & 9.200 .644 \\
\hline
\end{tabular}

\section{f. Rasio Penerimaan Atas Biaya Total / Kelayakan}

Untuk mengetahui besar kelayakan dalam usaha ternak ayam arab petelur di Desa Leppangang Kecamatan Patampanua Kabupaten Pinrang dapat di lihat pada Tabel 6 di bawah ini.
Tabel 6. Rekapitulasi Uji Kelayakan Usaha Ternak Ayam Arab Petelur di Desa Leppangang Kecamatan Patampanua Kabupaten Pinrang

\begin{tabular}{clr}
\hline No. & \multicolumn{2}{c}{ Uraian } \\
\hline 1 & Total penerimaan & 14.478 .000 \\
2 & Total Biaya & 5.277 .257 \\
\hline
\end{tabular}

\section{Aspek Non Finansial}

Setelah dilakukan pengumpulan data dan analisis data, hasil deskripsi dikelompokkan data skor dengan lima sub variabel, yakni aspek pemasaran, teknis, hukum, manajemen, sosal dan lingkungan, sebagai berikut:

\section{a. Aspek Pemasaran}

Hasil Penelitian Aspek non finansial terhadap kegiatan pada usaha ternak ayam arab petelur pada aspek pemasaran dapat di lihat di tabel 7 di bawah ini.

Tabel 7. Penilaian Aspek Non Finansial Terhadap Kegiatan Pada Usaha Ternak Ayam Arab Petelur di Desa Leppangeng

Kecamatan Patampanua Kabupaten

$$
\text { Pinrang }
$$

\begin{tabular}{clc}
\hline No & \multicolumn{1}{c}{ Indicator } & Jumlah Skor \\
\hline 1 & Produk & 45 \\
2 & Promosi & 43 \\
3 & Tempat atau distribusi & 43 \\
4 & Harga & 37 \\
\hline
\end{tabular}

\section{b. Aspek Teknis}

Hasil Penelitian tentang Aspek non finansial terhadap kegiatan pada usaha ternak ayam arab petelur pada aspek teknis dapat di lihat di tabel 8 sebagai berikut. 
Tabel 8. Penilaian Aspek Non Finansial Terhadap Kegiatan Pada Usaha Ternak Ayam Arab Petelur di Desa Leppangeng

Kecamatan Patampanua Kabupaten Pinrang

\begin{tabular}{clc}
\hline No & \multicolumn{1}{c}{ Indicator } & Jumlah Skor \\
\hline 1 & Lokasi usaha & 40 \\
2 & Penggunaan peralatan & 41 \\
\hline \multicolumn{2}{l}{ Sumber: } & Data Primer Setelah Diolah 2020
\end{tabular}

\section{c. Aspek Hukum}

Hasil Penelitian tentang Aspek non finansial terhadap kegiatan pada usaha ternak ayam arab petelur pada aspek hukum dapat di lihat di Tabel 9 sebagai berikut

Tabel 9. Penilaian Aspek Non Finansial Terhadap Kegiatan Pada Usaha Ternak Ayam Arab Petelur di Desa Leppangeng Kecamatan Patampanua Kabupaten Pinrang

\begin{tabular}{clc}
\hline No & \multicolumn{1}{c}{ Indicator } & Jumlah Skor \\
\hline 1 & Surat Izin Usaha & 34 \\
2 & Bukti pembayaran PBB & 44 \\
\hline \multicolumn{2}{l}{ Sumber: } & Data Primer Setelah Diolah 2020
\end{tabular}

\section{d. Aspek Manajemen}

Hasil Penelitian tentang Aspek non finansial terhadap kegiatan pada usaha ternak ayam arab petelur pada aspek manajemen dapat di lihat di tabel 10 sebagai berikut:

Tabel 10. Penilaian Aspek Non Finansial Terhadap Kegiatan Pada Usaha Ternak Ayam Arab Petelur di Desa Leppangeng

Kecamatan Patampanua Kabupaten Pinrang

\begin{tabular}{clc}
\hline No & \multicolumn{1}{c}{ Indicator } & Jumlah Skor \\
\hline 1 & SDM & 30 \\
2 & POACE & 39 \\
\hline
\end{tabular}

\section{e. Aspek Sosial dan Lingkungan}

Hasil Penelitian tentang Aspek non finansial terhadap kegiatan pada usaha ternak ayam arab petelur aspek sosial dan lingkungan dapat di lihat di tabel 11 sebagai berikut:

Tabel 11. Penilaian Aspek Non Finansial Terhadap Kegiatan Pada Usaha Ternak Ayam Arab Petelur di Desa Leppangeng

Kecamatan Patampanua Kabupaten Pinrang

\begin{tabular}{clc}
\hline No & \multicolumn{1}{c}{ Indicator } & Jumlah Skor \\
\hline 1 & Social & 43 \\
2 & Lingkungan & 35 \\
\hline Sumber: & Data Primer Setelah Diolah 2020
\end{tabular}

Total hasil penilaian Aspek Non

Finansial terhadap kegiatan usaha ternak ayam arab petelur di Desa Leppangang Kecamatan Patampanua Kabupaten Pinrang ditunjukkan pada Tabel 12.

Tabel 12. Hasil Rekapitulasi Aspek Non Finansial Usaha Ternak Ayam Arab Petelur

\begin{tabular}{llcl}
\hline Variable & \multicolumn{1}{c}{$\begin{array}{c}\text { Sub } \\
\text { Variabel }\end{array}$} & $\begin{array}{c}\text { Totak } \\
\text { Skor }\end{array}$ & Keterangan \\
\hline Aspek & $\begin{array}{l}\text { Aspek } \\
\text { pemasaran } \\
\text { Non }\end{array}$ & 168 & Setuju \\
Finansial & $\begin{array}{l}\text { Aspek } \\
\text { teknis }\end{array}$ & 81 & Setuju \\
& $\begin{array}{l}\text { Aspek } \\
\text { hukum } \\
\text { Aspek } \\
\text { manajemen } \\
\text { Aspek }\end{array}$ & 79 & Setuju \\
& $\begin{array}{l}\text { social dan } \\
\text { lingkungan }\end{array}$ & 78 & $\begin{array}{l}\text { Cukup } \\
\text { setuju } \\
\text { Setuju }\end{array}$ \\
\hline Sumber: Data Primer Setelah Diolah 2020 & \\
\hline
\end{tabular}

Penilaian tersebut meliputi lima sub variable yaitu, Aspek Pemasaran yang totalnya 168, Aspek Teknis totalnya 81, Aspek Hukum totalnya 79, Aspek Manajemen totalnya 69 dan Aspek Sosial dan Lingkungan totalnya 78. 


\section{f. Aspek Pemasaran}

Tabel 13 menunjukkan bahwa total nilai yang diperoleh dari Sub Variable Aspek Pemasaran adalah 168 skor termasuk kedalam kategori Setuju yang berada pada interval ( 139-171), dengan kategori Setuju, mengenai Aspek Non Finansial indikator Aspek Pemasaran dapat dilihat pada hasil rekapitulasi Indikator Aspek Pemasaran ditunjukkan pada Tabel 13 di bawah ini.

Tabel 13. Hasil Rekapitulasi Data Kuesioner Aspek Non Finansial Indikator Aspek Pemasaran Terhadap Kegiatan Usaha Ternak Ayam Arab Petelur

\begin{tabular}{clc}
\hline Kategori & & Skor \\
\hline Sangat tidak & ( STS ) & $=40 \mathrm{~S} / \mathrm{d} 72$ \\
setuju & & \\
Tidak setuju & ( TS ) & $=73 \mathrm{~S} / \mathrm{d} 105$ \\
Cukup setuju & ( CS ) & $=106 \mathrm{~S} / \mathrm{d} 138$ \\
Setuju & ( S ) & $=\mathbf{1 3 9}$ S/d 171 \\
Sangat setuju & ( SS ) & $=172 \mathrm{~S} / \mathrm{d} 204$ \\
\hline Sumber: Data Primer Setelah Diolah 2020 & \\
\multicolumn{2}{l}{ Pada aspek pemasaran jawaban }
\end{tabular}

responden, sebagai mengatakan bahwa telur dari ayam arab di sukai dan di butuhkan oleh konsumen di pasaran, karena telur dari ayam arab merupakan alternatif pengganti telur ayam kampung yang semakin langkah dipasaran.

Dalam sistem pemasaran telur ayam arab di Desa Leppangang Kecamatan Patampanua Kabupaten Pinrang, para peternak melakukan penjualan secara langsung kepada pembeli atau agen yang biasanya telah lama berlangganan, untuk penjualan telur ayam arab di jual dalam bentuk rak dengan jumlah 30 butir dalam satu rak, telur yang dimiliki oleh peternak di jual semua pada agen tanpa ada lagi yang disisakan, dalam transaksi ini peternak tidak menggunakan perantara atau biasa disebut tengkulak selama melakukan penjualan ini, para peternak tidak mengalami kesulitan apapun mengingat transaksi jual beli dilakukan secara langsung.

Sebagian konsumen kadang ada yang langsung ke peternakan untuk membeli telur ayam arab untuk di komsumsi. Para peternak mengatakan distribusi telur dari ayam arab berlangsung cepat dan lancar ke pedagang namun masih banyak masyarakat/ konsumen yang datang langsung ke peternakan untuk membelinya, hal ini disebabkan karena harganya berbedah, karena harga jual di kandang agak lebih murah di banding dengan harga di pasaran dan harga jualnya pun sudah termasuk sesuai dengan daya beli konsumen, telur dari ayam arab juga dipasarkan dan di krim ke luar kabupaten pinrang yaitu ke makassar, takalar, dan mamuju.

Bapak/ Ibu " Abd Gaffar dan P.daseng" Menggungkapkan bahwa terkadang ada masyarakat/ tetangga yang langsung datang untuk membeli 
telur,mereka mengatakan harganya lebih murah dan telurnya pun telur yang baru.

\section{Aspek Teknis}

Tabel 14 menunjukkan bahwa total nilai yang diperoleh dari Sub Variable Aspek Teknis adalah skor termasuk kedalam kategori Setuju yang berada pada interval 81 (71-87), mengenai Aspek Non Finansial indikator Aspek Teknis dapat dilihat pada hasil rekapitulasi Indikator Aspek Teknis ditunjukkan pada tabel 14 di bawah ini.

Tabel 14. Hasil Rekapitulasi Data Kuesioner Aspek Non Finansial Indikator Aspek Teknis Terhadap Kegiatan Usaha Ternak Ayam Arab Petelur

\begin{tabular}{ccc}
\hline Kategori & & Skor \\
\hline Sangat tidak setuju & ( STS ) & $=20 \mathrm{~S} / \mathrm{d} 36$ \\
Tidak setuju & ( TS ) & $=37 \mathrm{~S} / \mathrm{d}$ 53 \\
Cukup setuju & ( CS ) & $=54 \mathrm{~S} / \mathrm{d} 70$ \\
Setuju & ( S ) & $=\mathbf{7 1}$ S/d 87 \\
Sangat setuju & ( SS ) & $=88 \mathrm{~S} / \mathrm{d} 103$ \\
\hline Sumber: Data Primer Setelah Diolah 2020
\end{tabular}

Pada aspek teknis lokasi usaha ternak ayam arab petelur sebagian terletak di tengah-tengah pemukiman masyarakat / warga sehingga memudahkan pengenalan bahwa di tempat itu ada peternakan ayam arab petelur. Proses produksi yang dijalankan meliputi Proses pembersihan tempat pakan dan tempat air minum ternak, penyiapan pakan dan air untuk ternak, pemberian pakan dan pengisian air minum, dan pemanenen telur.

Kandang yang dimiliki peternak terdiri dari 1 kandang asli yaitu berupa kandang dalam tempat ternak dan sebagian peternak juga mempunyai kandang luar yaitu bangunan untuk kandang dalam.

Rata-rata peternak di Desa Leppangang Kecamatan Patampanua Kabupaten Pinrang melakukan usaha ternaknya di bawah kolom rumah sehingga mereka tidak membutuhkan kandang luar lagi/ bangunan untuk kandang dalam.

\section{Aspek Hukum}

Berdasarkan Tabel 14 menunjukkan bahwa total nilai yang diperoleh dari Sub Variable Aspek Hukum adalah 78 skor termasuk kedalam kategori Setuju yang berada pada interval (71-87),mengenai Aspek Non Finansial indikator Aspek Hukum dapat dilihat pada hasil rekapitulasi Indikator Aspek Hukum ditunjukkan pada Tabel 15 di bawah ini.

Tabel 15. Hasil Rekapitulasi Data Kuesioner Aspek Non Finansial Indikator Aspek Pemasaran Terhadap Kegiatan Usaha Ternak Ayam Arab Petelur

\begin{tabular}{ccc}
\hline Kategori & \multicolumn{2}{c}{ Skor } \\
\hline Sangat tidak setuju & ( STS ) & $=20 \mathrm{~S} / \mathrm{d} 36$ \\
Tidak setuju & ( TS ) & $=37 \mathrm{~S} / \mathrm{d} 53$ \\
Cukup setuju & ( CS ) & $=54 \mathrm{~S} / \mathrm{d} 70$ \\
Setuju & ( S ) & $=\mathbf{7 1 ~ S / d ~ 8 7}$ \\
Sangat setuju & ( SS ) & $=88 \mathrm{~S} / \mathrm{d} 103$ \\
\hline Sumber: Data Primer Setelah Diolah 2020 \\
Pada aspek hukum para peternak \\
ayam arab petelur di Desa & Leppangang \\
Kecamatan Patampanua & Kabupaten
\end{tabular}


Pinrang usaha peternakan mereka tidak memiliki izin usaha apa pun baik IMB ( izin mendirikan bangunan) SKDU (surat keterangan domisili usaha), akta pendiri, dan SIIP( surat izin usaha perdagangan) karena lokasi usaha yang mereka tempati ini masih dalam proses pengembangan dan usaha mereka masih tergolong masih baru atau belum lama berdiri tetapi peternakan ayam arab petelur yang memanfaatkan kolom bawah rumah warga itu sudah diketahui oleh Kepala Desa Leppangang Kecamatan Patampanua Kabupaten Pinrang tetapi tidak mempunyai izin secara tertulis.

Para peternak di Desa Leppangang Kecamatan Patampanua Kabupaten Pinrang hanya membayar pajak PBB, para peternak berpendapat surat- surat atau izin usaha dalam usaha ternaknya kata mereka tidak perluh karena peternakan mereka masih tergolong usaha skala kecil.

Wawancara dengan salah satu peternak Bapak Labidi “ Saya rasa usaha ternak saya ini tidak peluh mengurus namanya surat izin usaha karena usaha saya ini masih dalam kategori skala kecil dan yang paling penting usaha ini hanya didirikan di bawah kolom rumah, kita hanya taunya bayar PBB, kepala desa dan staf kantor desa hanya mengetahui jika kita melakukan usaha ternak skala kecil ini di rumah, kalau masalah persuratan itu belum ada arahan dari kantor desa untung mengurusnya.

\section{Aspek Manajemen}

Tabel 15 menunjukkan bahwa total nilai yang diperoleh dari Sub Variable Aspek Manajemen adalah 69 skor termasuk kedalam kategori Cukup Setuju yang berada pada interval (5470), mengenai Aspek Non Finansial indikator Aspek Manajeman dapat dilihat pada hasil rekapitulasi Indikator Aspek Manajemen di tunjukkan pada tabel 16 di bawah ini.

Tabel 16. Hasil Rekapitulasi Data Kuesioner Aspek Non Finansial Indikator Aspek Manajemen Terhadap Kegiatan Usaha Ternak Ayam Arab Petelur

\begin{tabular}{ccc}
\hline Kategori & & Skor \\
\hline Sangat tidak setuju & ( STS ) & $=20$ S/d 36 \\
Tidak setuju & ( TS ) & $=37$ S/d 53 \\
Cukup setuju & ( CS ) & $=\mathbf{5 4}$ S/d 70 \\
Setuju & ( S ) & $=71$ S/d 87 \\
Sangat setuju & $($ SS $)$ & $=88$ S/d 103 \\
\hline Sumber: Data Primer Setelah Diolah 2020
\end{tabular}

Pada aspek manajemen jawaban responden, sebagai mengatakan bahwa usaha ternak ayam arab telur ini membutuhkan tenaga kerja dan ada pula yang tidak membutuhkan tenaga kerja.

$$
\text { Ramlah menggungkapkan " Saya }
$$
rasa usaha ternak ayam arab petelur sayang tidak harus menggunakan tenaga kerja kan jumlah hanya sedikit saya sendiri pun mampu mengurus ternak saya” 
Saru menggungkapkan" Dalam usaha ternak ayam arab petelur ini saya menggunakan tenaga kerja dari masyarakat sekitar sini/ tetangga saya, karena saya sering merasa kewelahan dalam memelihara ternak saya"

Dalam melakukan kegiatan usaha ternak ayam arab petelur para peternak yang ada di Desa Leppangang Kecamatan Patampanua Kabupaten Pinrang, sebelumnya harus ada kegiatan perencanaan sebelum usahanya dilakukan dan melaksanakanya, agar tidak terjadi suatu kesalahan yang nantinya akan merugikan kegiatan usaha ternak mereka, kegiatan usaha ternakmereka di kelola secara baik menerapkan konsep fungsifungsi manajemen.

\section{a. Perencanaan ( Planning)}

Kegiatan usaha ternak yang dijalankan oleh Peternak ayam arab petelur tentunya memiliki perencanaan yang telah dilakukan sebelum usahanya dilaksanakan tujuannya agar kegiatan usahanya dapat berjalan sesuai dengan yang diharapkan.

Untuk perencanaan peternak di Desa Leppangang Kecamatan Patampanua Kabupaten Pinrang sebelum kegiatan usaha dilakukan para peternak menyiapkan semua yang dibutuhkan dalam proses pemeliharaan ayam arab petelur terutama kandang dan lokasi.

\section{b. Organisasi( Organizing)}

Peternak di Desa Leppangang Kecamatan Patampanua Kabupaten Pinrang tidak memiliki struktur organisasi dalam hal ini mereka tidak tergabung dalam suatu kelompok, sebagian besar peternak melaksanakan kegiatan usahanya secara individu.

\section{c. Pengarahan( Actuating) dan Peng awasan ( Cotrolling)}

Pengarahan bertujuan untuk melihat bagaimana cara peternak/ tenaga kerja melakukan pekerjaannya dalam hal ini adalam proses pemeliharaan ternak, kegiatan pengarahan hanya dilakukan khusus pada peternak yang memiliki tenaga kerja yang disewa pada saat proses pemiliharaan ternak.

Sedangkan Pengawasan proses untuk mengukur dan menilai pelaksanan tugas apakah telah sesuai dengan rencana, pengawasan diperluhkan dalam melihat apakah dari rencana yang telah dilaksanakan tersebut dapat memenuhi sasaran yang telah dibuat atau belum.

\section{d. Evaluasi}

Dalam kegiatan usaha ternak ayam arab petelur, para peternak perluh melakukan kegiatan evaluasi agar dapat diketahui hal-hal aapa saja yang perluh 
diperbaiki, di tingkatkan, mau pun diatur kembali baik dari sistem pemeliharaan hingga pemasaran. Dari seluruh kegiatan dari awal sampai akhir usaha ternak ayam arab petelur rata-rata para peternak memiliki kendala yaitu pada saat penjualan telur karena penjuala telur mereka menggunakan trasportasi/mobil untuk membawah telur mereka ke agen terkadang mobil yang mereka gunakan di sewa juga oleh peternak lain misalyanya peternak ayam ras petelur dan juga harga yang kadang berubah-ubah dari yang terendah sampai yang tertinggi. Tetapi para peternak mengakui bahwa usaha ternak ayam arab petelur ini termasuk menguntungkan dan sudah bisa membantu perekonomian keluarga mereka.

\section{e. Aspek Sosial dan Lingkungan}

Tabel 16 menunjukkan bahwa total nilai yang diperoleh dari Sub Variable Aspek Sosial dan Lingkungan adalah 78 skor termasuk kedalam kategori Setuju yang berada pada interval (7187), mengenai Aspek Non Finansial indikator Aspek Sosial dan Lingkungan dapat dilihat pada hasil rekapitulasi Indikator Aspek Sosial dan Lingkungan di tunjukkan pada tabel 17 di bawah ini.
Tabel 17. Hasil Rekapitulasi Data Kuesioner Aspek Non Finansial Indikator Aspek Sosial dan Lingkungan Terhadap Kegiatan Usaha Ternak Ayam Arab Petelur

\begin{tabular}{ccc}
\hline Kategori & Skor \\
\hline Sangat tidak setuju & ( STS ) & $=20$ S/d 36 \\
Tidak setuju & ( TS ) & $=37$ S/d 53 \\
Cukup setuju & $($ CS ) & $=54$ S/d 70 \\
Setuju & ( S ) & $=71$ S/d 87 \\
Sangat setuju & ( SS ) & $=88$ S/d 103 \\
\hline Sumber: Data Primer Setelah Diolah 2020
\end{tabular}

Pada aspek sosial dan lingkungan sebagian responden menyatakan Setuju peternakan ayam arab petelur berdampak terhadap Aspek sosial dan lngkungan. Pada indikator Sosial yaitu banyaknya lalat, hal ini di sebabkan penanganan lalat ini tidak begitu menjadi prioritas utama bagi peternak ayam arab petelur banyaknya lalat berkembang biar dan tidak ditangani sehingga lalat masuk kedalam rumah warga terkhusus yang sangat dekat dengan peternakan padahal lalat dapat membawa penyakit, karena dianggap biasa sehingga tidak ada penanganan yang dilakukan akibatnya banyak lalat di sekitar peternakan ayam arab petelur, lalat yang ditimbulkan oleh peternakan sangat mengganggu bagi masyarakat sekitar.

Hal ini sesuai dengan pendapat Santoso (2010) Bahwa selain mengganggu lalat juga menimbulkan banyak penyakit, misalnya : desentri, diare, typoid, dan colera.

Masyarakat di Desa Leppangang 
Kecamatan Patampanua Kabupaten Pinrang tidak begitu resah dengan penyebaran penyakit/ virus karena para peternak ayam arab petelur sudah mulai menyadari bahwa vaksinasi dan penyemprotan di kandang ternak itu sangat perluh untuk menghindari penyakit/ virus sehingga peternak sudah melakukan pencegahan, pengendalian , dan pemberantasan penyakit.

Bersadarkan wawancara dengan para peternak ayam arab petelur di Desa Leppangang Kecamatan Patampanua Kabupaten Pinrang para peternak sudah melakukan pencegahan dengan melakukan vaksinasi dan penyemprotan pada hewan ternak mereka.( Abd. Gaffar dan Lamba)

Hal ini sesuai dengan pendapat Sauvan (2011) vaksinasi ini bertujuan untuk menstimulasi dan sangat perlu dilakukan oleh peternak untuk pembetukan anti bodi yang sesuai dengan jenis vaksin yang di berikan.

Pada indikator Lingkungan sebagian respeonden menyantakan Cukup Setuju, dimana peternakan ayam arab petelur di Desa Leppangang Kecamatan Patampanua Kabupaten Pinrang menimbulkan Bau yang kurang sedap yang berasal dari kandungan gas amonia yang tinggi yang bertentuk dari penumpukan fases yang masih basah, hal Ini sesuai dengan pendapat Santoso (2009) bahwa peternakan ayam menimbulkan gas amonia yang mempunyai pengaruh buruk terhadap manusia.

Hasil yang di dapatkan di lokasi sebahagian peternak masih menumpuk limbah kotoran di sekitar kandang dan terkadang peternak pun memmberikan izin kepada masyarakat atau petani di sekitaran peternakan yang ingin mengambil kotoran ternak tersebut untuk di jadikan pupuk organik, akan tetapi pengangkutan limbah fases oleh petani atau masyarakat tidak selalu di lakukan sehingga fases lebih lama menumouk dan menimbulkan bau. Air yang berasal dari pembersihan ternak juga menimbulkan bau yang didak sedap hal ini di sebabkan karena saluran air di peternakan tidak berfungsi dengan baik dan tidak kurang di perhatikan sehingga air dari pembersihan ternak tersebut mengendap dan menimbulkan bau.

\section{KESIMPULAN DAN SARAN}

Hasil penelitian dan pembahasan dapat ditarik kesimpulan bahwa pendapatan semua peternak dalam usaha ternak ayam arab petelur di Desa Leppangang Kecamatan Patampanua Kabupaten Pinrang adalah sebanyak 
Rp.92.006.435/ Bulan dengan pendapatan rata-rata Rp. 9.200.644/ bulan dengan biaya perbulan sebesar Rp.52.773.565 dengan rata-rata biaya yang di keluarkan sebesar Rp. 5.277.357/ bulan.

Tingkat kelayakan usaha beternak ayam arab petelur ditinjau dari analisis Finansial Layak untuk dikembangkan. Tingkat kelayakan usaha ternak ayam arab petelur ditinjau dari Aspek non Finansial Layak untuk dikembangkan.

\section{DAFTAR PUSTAKA}

Arikunto, 2008. Prosedur Penelitian suatu pendekatan praktek. Penerbit PT. Rineka Cipta, Jakarta.

Latifah, M, 2007. Persepsi dan Ekspektasi Terhadap Propesi Psikologi (Penelitian Deskriptif Pada Mahasiswa Psikologi Universitas Negeri Semarang Tahun 2007).

Mulyadi. 2008. Sistem Akuntansi. Jakarta : Salemba Empat.

Mulyadi. 2009. Akuntansi Biaya. Yogyakarta : STIE YPKPN

Pambudhi, W, 2003. Beternak Ayam Arab Merah Si Tukang Bertelur. Agromedia Pustaka. Depok.

Santoso, 2009. Mengelola Peternakan sapi Secara Profesional. Penebar Swadaya, Jakarta

Sauvan, 2011. Vaksinasi dan Penyakit. :http// media hidup. Blog.com/2011/05/ vaksinasi-danpenyakit.html (Diakses Pada Tanggal 25 Januari 2020).

Soekartawi, 2011. Ilmu Usaha Tani. Universitas Indonesia : Jakarta.

Sukirno, 2006. Ekonomi Pembangunan. Proses, Masalah dan Kebijakan, Kencana Prenada Media Grup.
Syamsuddin, 2009. Rasio dan Prediksi Perubahan Laba Perusahaan Manufaktur Yang Terdaftar Di Bursa Efek Indonesia. Fakultas Ekonomi Universitas Muhammadiyah. Surakarta. BENEFIT Jurnal Manajemen Dan Bisnis Volumen 13, Nomor 1 Juni 2009. 